ADDIN, Volume 11, Number 1, February 2017

\title{
BUILDING THE TRANSFORMATIVE ISLAMIC CIVILIZATION: Reaserch on Gait of K.H. M.A. Sahal Mahfudh
}

\author{
Jamal Ma'mur \\ Institut Pesantren Mathaliul Falah Pati, Central Java, Indonesia \\ jamal_mamur@yahoo.com
}

\section{Abstract}

Historical evidence shows that K.H. M.A. Sahal Mahfudh is building the transformative Islamic civilization towards $g$ a prosperous, fair, and progressive Muslim community buildings. Kiai Sabal Mabfudh encourages Muslims to be the best people able to provide profusely expediency to others. According to Kiai Sabal Mahfudh, the best people are productive people, the man who is sensitive to the needs of the environment, controlling information, having organizational competence and high creativity, so that they can create jobs and grow the economy comprehensive insight. For these ideals, the aspect of education, health, and the economy must be developed maximally. These three fields are interrelated and inseparable. Transformative Islamic civilization championed by Kiai Sabal Mahfudh is relevant to maqasidus sharia theory, that is the Islamic law which purposes to keep religion, keep the soul, keep the property, keep the mind and keep the offspring. Kiai Sabal Mabfudh struggle in improving the quality of education in boarding school and university Maslakul Huda, Islamic Mathaliul Falab Kajen in order to keep religion and 
reason. Economic empowerment in BPPM and BPR Artha Huda Abadi in order to keep the property. While the struggle of Kiai Sahal Mahfudh in establishing Islamic Hospital Pati in order to preserve life and heredity. This study is a qualitative research with the primary sources of Kiai Sahal Mahfudh works. The result of this study is analyzed by the theory of maqasid asy-syari'ah.

Keywords: Social Fiqh, Islamic Civilization, Transformative, Maqāsid asy-Syari'iah.

\section{Abstrak}

Bukti sejarah menunjukkan bahwa K.H. M.A. Sahal Mabfudh membangun peradaban Islam transformatif menuju bangunan komunitas Muslim yang makmur, adil, dan progresif. Kiai Sahal Mahfudh mendorong umat Islam untuk menjadi orang terbaik yang mampu memberikan kemanfaatan yang besar kepada orang lain. Menurut Kiai Sahal Mahfudh, orang terbaik adalah orang produktif, orang yang peka terhadap kebutuhan lingkungan, mengendalikan informasi, memiliki kompetensi organisasi dan kreativitas tinggi, sehingga bisa menciptakan lapangan kerja dan menumbubkan wawasan ekonomi yang menyeluruh. Untuk cita-cita ini, aspek. pendidikan, kesehatan, dan ekonomi harus dikembangkan secara maksimal. Ketiga bidang ini saling terkait dan tidak terpisabkan. Peradaban Islam transformatif yang diperjuangkan oleh Kiai Sabal Mahfudh relevan dengan teori maqāsid asy-syari'ah, yaitu bukum Islam yang bertujuan menjaga agama, menjaga jiwwa, menjaga barta benda, menjaga pikiran, dan menjaga keturunan. Kiai Sabal Mabfudh berjuang dalam meningkatkan kualitas pendidikan di pesantren dan universitas Maslakul Huda, Mathaliul Islam Falah Kajen untuk menjaga agama dan akal. Pemberdayaan ekonomi di BPPM dan BPR Artha Huda Abadi untuk menjaga properti. Adapun perjuangan Kiai Sahal Mahfudh dalam membangun Rumah Sakit Islam Pati dalam rangka melestarikan kehidupan dan keturunan. Penelitian ini merupakan penelitian kualitatif dengan sumber utama 
karya Kiai Sahal Mahfudh. Hasil penelitian ini dianalisis dengan teori maquasid asy-syari'ah.

Kata Kunci: Figh Sosial, Peradaban Islam, Transformatif, Maqāsid asySyariah.

\section{A. Introduction}

Islamic civilization was built by the Prophet Muhammad, continued by their companions, and by succeeding generations. They upheld the values of divinity, humanity, equality, social justice, economic justice, truth and solidarity. ${ }^{1}$ Civilizations are physical activity that aims to fight for the things ahead, beautiful and delicate of culture, such as arts, science, social customs and manners, cleverness in writing, state organizations, and others. Islamic civilization involves moral aspect, art, science, technology system, architecture art, state system, and extensive knowledge. ${ }^{2}$ Harun Nasution made a classification of Islamic civilization into three.

First, the classic period. The classic period is divided into two phases. First, the expansion phase, integration and the top progress is in 650-1000 AD. At this time the Islamic territories already spread to Spain and India. Science, both in the religious and non-religious was growing rapidly, so that the great scientists was born, such as Imam Abu Hanifah, Imam Malik, Imam Shafi'i, Imam Ibn Hanbal in the fields of Islamic law, Imam al-Ash'ari, Imam al-Maturidi of Sunni, Wasil Ibn 'Ata', Abu al-Huzail, an-Nazzam, and al-Jubbai from Mu'tazila, Zunnun al-Misri, Abu Yazid al-Bastami, and al-Hallaj in the field of Sufism, al-Kindi, Ibn Sina, al-Farabi, and Ibn Miskawayh in philosophy, and Ibn al-Haytham, Ibn

\footnotetext{
${ }^{1}$ Fazlur Rahman, Islam (US: University of Chicago, 1979), p. 25.

${ }^{2}$ M. Abdul Karim, Sejarah Pemikiran dan Peradaban Islam (Yogyakarta: Bagaskara, 2012), p. 34-36.
} 
Hayyan, al-Khwarizmi, al-Mas'udi, and ar-Razi in the field of knowledge. The second phase is disintegration that took place in the years 1000-1250 AD. During this period, internal splits occured, the caliph power decreased, and the peak occured when Baghdad as a symbol of Islamic power was conquered by Hulagu in 1258 AD. $^{3}$

Second, the medieval period that is divided into two phases. First, the slowdown phase in 1250-1500 AD. In this phase, disintegration and decentralization increased. Differences Shiite and Sunni, Arab and Persian was increasingly visible. Polarization of the Islamic world appeared, which was part of the Arab consisting of Arabia, Iraq, Syria, Palestine, Egypt, and Africa whose center was in Egypt, and parts of Persia which consists of the Balkans, Asia Minor, Persia, and Central Asia whose center was in Iran. At this time, the understanding that ijtihad had been closed more widespread and steady. The negative effects of tarekat was clear and attention of Muslims to science was very less. Muslims in Spain were forced to convert to Christianity or to be out of the country. Second, three great kingdoms phase, namely the Ottoman Empire in Turkey, Safawi Empire in Persia and Mughal Empire in India, starting with the time of progress in the year 1500 to $1700 \mathrm{AD}$ and setback age in the year 1700 to 1800 AD. During the the glory of this three kingdoms stood mosques and a beautiful building in Istanbul, Tibriz, Isfahan, and other cities in Iran and Delhi. At this time, the attention to science was reduced. In the setback age, the Ottoman Empire was hit in Europe, the Safavid empire was destroyed by the Afghans, and the Mughal empire was attacked by the kings of India. When Muslims military and political power was decreased, Europe

${ }^{3}$ Harun Nasution, Pembaharuan dalam Islam: Sejarab Pemikiran dan Gerakan (Jakarta: Bulan Bintang, 2003), p. 5. 
experienced the glory whose peak occurred in 1798 AD when Napoleon occupied Egypt. ${ }^{4}$

Third, the modern period that occurred in 1800 AD to the present. This period became Muslim recovery from a setback. Muslims are consciously aware that the fall of Egypt into the hands of the West show a new civilization that create a serious threat to Muslims. The leaders of the Muslims begin to think how to improve the quality and strength of Muslims in order to be able to compete with the West. At this time, the renewal ideas of Islam is born. ${ }^{5}$ In the West, revolution occurs in many aspects. New techniques in the manufacture and industrial organization are adopted to give encouragement due to the needs and energy caused by the war. After the war ended, trade move freely, the world becomes open to the products like cheap cotton, wool clothes, and metal goods from Britain, France, Belgis, Switzerland, and West Germany. In the field of transportation there are steamer and train. The communication is moving fast, so that the growth of international financial markets running quickly. Trading profits are invested to generate new production activities. On the other hand, the armed forces are growing rapidly. ${ }^{6}$ The reformers start to think how to restore the balance of power. Thoughts about how Muslims progress as the old period push forward dynamically. ${ }^{7}$ One of the prominent figures who act as a catalyst reformer is Jamaluddin al-Afghani (1897) which taught Pan Islamic solidarity and defense against European imperialism by returning to the teachings of Islam modernized. The reform movement in the Middle East has a major influence on the rise of Islam in Indonesia

\footnotetext{
${ }^{4}$ Ibid., p. 6.

${ }^{5}$ Harun Nasution, Pembaharuan dalam Islam, p. 5.

${ }^{6}$ M. Abdul Karim, Sejarah Pemikiran dan Peradaban Islam, p. 347.

${ }^{7}$ Harun Nasution, Islam Ditinjau dari Berbagai Aspeknya, jilid 1 (Jakarta: UI Press, 2008), p. 86.
} 
with the birth of political and socio-religious organizations who voiced the Islamic reform. ${ }^{8}$

Deterioration of Islamic civilization is caused by two factors. First, hedonism and pragmatism that hit Muslims when it was in the top of power. They forgot themselves when they were in power. Glamor, arrogance, and greed become a way of life which was contrary to the teachings of Islam. Second, dynamism and transformation of western nations in developing science and technology. Western was not dazzled by the progress of Islam, but they quickly studied Islam and developed it productively to produce monumental works that were not previously imagined by Muslims, particularly in the field of science and technology.

In this context, there is no other way for the muslims to build the future of civilization but to do two tasks at once, namely internalizing the religious character and dynamics of science and technology to be an integral and synergistic. This gave rise to a wide reform in Islam with different terminology, suh as:

First, Islam Rational encouraging ijtihad as a mechanism of interpretation or renewal of Islamic doctrine. This rational Islamic movement bring the courage of young thinkers of Islam in displaying individual freedom in dealing with the mind of Islam and outside of Islam, such as the Western philosophical tradition. Second, Islam scientific striving to build a modern image of Islam as a religion, to modernize the traditional Islamic institutions, and open the door of ijtihad. This movement is done so that Islam is able to respond to the modernization and acculturation to the culture and customs of Islam. Third, Islam Critical that seeks to align the definition, understanding, and practice the teachings

${ }^{8}$ Badri Yatim, Sejarah Peradaban Islam (Jakarta: RajaGrafindo Persada, 2011), p. 
of Islam. This is done in a way to educate and mature the understanding of Muslims and fortify the Muslims in order not to be affected into misguided and misleading religion, ideology, and doctrine.

Fourth, Islam desacralization which affirms the understanding that the interpretation of the Qur'an and Sunnah can be different and changed so that Muslims do not experience stagnation and loss psychological striking force. Truth and absolute transcendence belongs only to God, so that the renewal of Islamic thought becomes a necessity. Fifth, Native Islam who put Islam as a complementary factor in the formation of social structure, culture and politics in Indonesia. In the process of indigenization, should not mix Islam and local culture, even when they understand Islam must consider local contexts, but the main feature of Islam should be retained in the original form. Therefore, reading the Qur'an when praying should be pronounced in Arabic. Sixth, Islam of Civilization encourages the study of the Qur'an in a comprehensive manner. The first step is to understand the meaning or the meaning of the statement in the Qur'an by reviewing historical situations or problems showing that the Qur'an is the answer. The second step is to generalize specific answers and mention a statement that has a common socialmoral purpose which can be found on the specific verse seen from sociological-historical studies and logical ratio which is often questioned. With these two steps, then Muslims can understand the ethical basis of a verse with historical and contextual analysis and able to interpret, clarify and answer contemporary problem with the ethical spirit of the Qur'an obtained through the profound study. ${ }^{10}$

\footnotetext{
${ }^{9}$ Aden Wijdan S.Z., dkk., Pemikiran dan Peradaban Islam (Yogayakarta: PSI UII and Safiria Insania Press, 2007), p. 110-118.

${ }^{10}$ Ibid., p. 118-132.
} 
Seventh, Islam of re-actualization that encourages islamic thinkers to be able to respond to the real needs of people. In this context, re-actualization is needed by in order that islamic articulation relevant to the situation and condition of Indonesia. Eighth, Islam transformative focuses on the problems of backwardness of Muslims caused by injustice relationship between developed world and the third world because imperialistic character. Islam transformative tries to generate thoughts that are not utopian-normative, capable of expanding horizons, produce useful materials in planning social engineering appropriately concerning to the development of society, and to save Muslims from the idea into the legitimacy of totalitarian management patterns. Ninth, Islam of integralist stating that there is compatibility of Islam with the findings of contemporary science. The structure of science can be accessible with elements of Islam. Suitability of contemporary science with Islam is in the level of metaphysics. ${ }^{11}$

Tenth, Islam of substantive developing moral messages with central themes such as justice and egalitarianism and does not highlight the symbol is. Eleventh, dynamic-dialogical cultural Islam concerning to aspects of morality, aesthetics, ecology, economics, human rights, and the relationship of men and women in understanding the teachings of Islam. Twelfth, Islam of exclusive which believes that beliefs, views, thoughts and principles professed by others are wrong, misguided and should be avoided. While beliefs, views, thoughts and principles of theirs are the right one. Narrow views and attitudes that only know one mazhab of theology, fiqh, Sufism and others become the cause of the birth of exclusive Islam. Thirteenth, inclusive-pluralist Islam that believes in other religions of the world have some truth

${ }^{11}$ Ibid. 
and able to provide benefits and safety for adherents. The religions in the world begin to adopt an inclusive attitude and aware to understand the religious experiences of other people. In this case, dialogue is the key. ${ }^{12}$

Fourteenth, Islam of humanist doing initiation, appreciation, elaboration, and development activities aimed to show that Islam is more aligned to the empowerment of people and communities with a scientific approach. Islamic values appreciated and internalized in the form of research, training, discussions and seminars and publishing as a means of empowerment. Fifteenth, Islam of liberal struggling Islamic thought enthusiastically. One of liberal Islamic thought is a legal institution in Islam is always concerned with the tradition of the community, so at the time of the Prophet many local cultures were adopted in the law system the sacred religion, so that the Islamic sharia should adopt the tradition of law in the local community. Sixteenth, the Islamization of the economy by encouraging the study of Islamic economics in college and the establishment of Islamic financial institutions. ${ }^{13}$

One of the figures who succeeds to build a renewal of Islamic civilization with transformative pattern is K.H. M.A. Sahal Mahfudh, former of Rais Am Nahdlatul Ulama (NU) and the Center Chairman of the Indonesian Ulama Council (MUI). This paper will explore the thoughts and struggles of K.H. M.A. Sahal Mahfudh in building the Islamic civilization based on transformative religious ethics and dynamics of science and technology in order to build the future of Islam rạ̣matan li al-álamin. This study is a library research. Theoretical framework used is transformative Islamic civilization with maquasid asy-syari' ${ }^{\prime}$ ah analysis.

\footnotetext{
${ }^{12}$ Ibid., p. 118-132.

${ }^{13}$ Ibid.
} 


\section{B. Discussion}

\section{Biography of K.H. M.A. Sahal Mahfudh}

Ulama (theologian) according to K.H. Ali Ma'shum is divided into two. First, scholars with standard scientific capacity, which can read the Qur'an and the salaf book, able to understand the book of Taqrib or Fath al-Mu'in in the field of fiqh, Tafsir al-Jalalain, and Riyặ as-Salihịin or Bulug alMaram for hadis. To achieve this standard competency, one must master nahwu and sharf. Secondly, mutafaqqih scholars with superior capacity who master Arabic science to the law-making methods (istinbat), such as ușul al-fiqh and qawa'id al-fiqh, understanding the science of comparative mazhab, and capable of reading the development of society and the times. $^{14}$

While Imam al-Ghazali divides ulama into two, namely hereafter scholars and the world scholars. hereafter scholars have the characteristics: do not use science for the purpose of worldly, consequent to what is said, prefers eschatology, simple and ascetic and not interested in the luxuries of life, keeping away from the king, not hasty in giving fatwa, pay attention to inner science and supervising all movements of souls (muraqabab), enhancing confidence, being sad and fear to God in all things, giving priority to the study of practiced science, reaching knowledge that hung by the power of inner vision, and very cautious towards new things. While the characteristics of the world scholars are: using science to the world, fasiq (happy to commit a sin intentionally), ostentatious, their science does not bring them to God, articulate, his conscience does not alive, doing evil because they always violate religion rules, and often do immoral knowingly. ${ }^{15}$

\footnotetext{
${ }^{14}$ Ibid.

${ }^{15}$ Abdurrahman Mas'ud, Reproduksi Ulama di Era Globalisasi, p. 277-279.
} 
In the above context, we examine the figure of K.H. M.A. Sahal Mahfudh from the track records can be classified into the afterlife scholars or ulama mutafaqqih. K.H. M.A. Sahal Mahfudh is the figure of student, teacher, the leader, and agent of change who is born from pesantren. K.H. Sahal Mahfudh was born on December 17, 1937 AD. His parents are K.H. Mahfudh Salam and Mrs. Badi'ah. His childhood was spent in Kajen, a village inhabited by dozens of boarding schools with the central figure of K.H. Ahmad Mutamakkin. The relationship of K.H. Sahal Mahfudh with K.H. Ahmad Mutamakkin, namely K.H. M.A. Sahal Mahfudh bin K.H. Mahfudh Salam bin K.H. Abdussalam bin K.H. Abdullah binti Nyai Mutiroh binti K.H. Bunyamin binti Nyai Toyyibah binti K. Endro Muhammad bin K.H. Ahmad Mutamakkin. ${ }^{16}$

Since childhood, he learnt to his father K.H. Mahfudh Salam al-Hafidh and at Mathali'ul Falah Islamic School (PIM) Kajen which is an educational institution pioneered by his grandfather K.H. Abdussalam and continued by his father K.H. Mahfudh Salam. Qur'an and yellow books are the main lesson learnt by K.H. Sahal Mahfudh as a foundation of knowledge that will be lifted to a higher level. In addition to studying religion, Kiai Sahal Mahfudh also studied general sciences by following courses, such as administration, state governance, English, and others.

After finishing from PIM Kajen, Kiai Sahal Mahfudh continued learning in Bendo boarding school who was raised by K.H. Muhajir. Here, Kiai Sahal Mahfudh steeped in tasawuf, balaghah, and interpretation. Finishing from Bendo, Kiai Sahal Mahfudh continued his odyssey to Sarang Islamic boarding school which are taught by K.H. Maimun

\footnotetext{
${ }^{16}$ Jamal Ma'mur, dkk., Mempersiapkan Insan Sholih-Akrom: Potret Sejarah dan Biografi Pendiri-Penerus Perguruan Islam Mathali'ul Falab Kajen Margoyoso Pati 1912-2012 (1 Abad) (Pati: PIM, 2012), p. 111.
} 
Zubair. Here, Kiai Sahal Mahfudh explored alat science, fiqh, usul fiqh, qawaid figh, tafsir, hadith, and others. After that, Kiai Sahal Mahfudh was back to his hometown in Kajen to continue leadership in Maslakul Huda Islamic boarding school which was pioneered by his father and continued the leadership of Mathali'ul Falah Islamic School who was pioneered his grandfather.

Kiai Sahal Mahfudh's leadership was seen since he led PIM Kajen and bahtsul bahtsul Margoyoso forum named Raudah al-Musyawarah. Kiai Sahal Mahfudh career increased fast, ranging from sub-district, district, province, to the center as Rais Am Nahdlatul Ulama (NU) and the Chairman of the Indonesian Ulama Council (MUI) for three consecutive periods. His Career in organization was equipped with intellectual achievement with the birth of the quality works that is able to break the stagnation of ideas in the pesantren, such as Tariqah al-Husūul 'ala Syarḅi Gayah al-Wușul, al-Bayān al-Mulamma 'an Alfara al-Lumā', Nuansa Fiqih Sosial, Pesantren Mencari Makna, Wajah Baru Fiqh Pesantren, Dialog dengan Kiai Sahal Mahfudh, and others. ${ }^{17}$

Kiai Sahal Mahfudh success in the work and career was influenced by his father K.H. Mahfudh Salam alHafidh who always kept up information, discipline, and have a noble character, especially to parents. Kiai Mahfudh was also as a manager of educational institutions, namely the Islamic Institution of Mathali'ul Falah. ${ }^{18}$ His discipline and deep science and broad insight made him as a highly respected figure. The ideals of Kiai Mahfudh inspired Kiai Sahal Mahfudh in developing science, mobilized constructive change in society, and leading educational institutions in a dynamic and competitive way.

${ }^{17}$ Ibid., p. 111.

${ }^{18} \mathrm{Ibid}$. 
In addition, another figure who gave great influence on Kiai Sahal Mahfudh is Syekh Yasin al-Fadani bin Isa al-Makki. Hadith scholar who lived and passed away in Makkah gave the fundamentals science of hadith to Kiai Sahal Mahfudh and trained how to deliver answers with strong arguments. Syekh Yasin certified ammah to Kiai Sahal Mahfudh so that Kiai Sahal Mahfudh had sanad (genealogy of science) of books up to the author's book of Syekh Yasin. ${ }^{19}$

Kiai Sahal Mahfudh's habits since at the school which made him a great people was: First, his incredible spirit in reading. The books were read by Kiai Sahal Mahfudh not only the yellow books, but also newspapers, magazines, comics, books, and others who could develop and enlarge his thoughts and worldview. His Intellectual exploration began from hundreds or even thousands of yellow books, ranging from basic to the most high, as well as books, magazines, newspapers, and other very useful materials to keep broad of information and knowledge as the main capital to respond to the actual problems in a positively, constructively, and contextually.

Second, his high spirit in writing. He always wrote the explanation of teachers ( ta $^{\prime}$ liq) and provided an explanation of the existing texts (syarh) developed by Kiai Sahal Mahfudh seriously, so he was able to write high quality works, both Arabic and Indonesian language. Book of Tariqah al-Husü 'ala Syarḅi Gayah al-Wusüul was born when Kiai Sahal Mahfudh taught book of Lubb al-Ușul by Zakariyya al-Ansari in Pesantren Sarang. Before teaching, Kiai Sahal Mahfudh first read and wrote important notes.

The notes were then systematized and fitted into a monumental work. Anwär al-Bașäir fi Syarḅi al-Asybab wa

${ }^{19}$ Ibid. 
an-Nada'ir, syarb of al-Asybah wa an-Nada'ir by Jalaluddin asSuyuti is the notes of Kiai Sahal Mahfudh when learnt that book with Syekh Zubairi Dahlan, father of K.H. Maimun Zubair. Intifăh al-Wajadain fi Muñadarab 'Ulama' Hajain is the book of Kiai Sahal Mahfudh documentation on intensive discussions among scholars in Kajen and surrounding areas. It is about the law of the goods sold by the glasses. Kiai Sahal Mahfudh also wrote papers in various discussion forums which were then collected in several books, such as Nuansa Fiqh Sosial, Pesantren Mencari Makna, Dialog dengan K.H. M.A. Sabal Mahfudh, and others.

Third, He liked discussing. Since he studied at the Mathaliul Falah Islamic School, he had been active to ask the teacher in the classroom when he found difficulty in understanding lesson. As in Pesantren Bendo, Kiai Sahal Mahfudh already initiated a discussion forum with the form book of balaghah Jauharah al-Maknūn, ushul figh and fiqh al-Luma'. This discussion forum ran well. At the pesantren indeed provided a scientific discussion forum called Bahtsul Masa'il Diniyyah to discuss social issues that need answers from the perspective of Islamic law derived from the yellow books. ${ }^{20}$

Fourth, he liked to organize. Since in Kajen, Bendo, Sarang, and back to Kajen again Kiai Sahal Mahfudh was active in the organization. That organization had the great influence in delivering success to him. Organization could be an effective medium to develop networks, cooperation, and self-potential actualization maximally. His intelligence in the organization didn't break his responsibilities to family and pesantren.

${ }^{20}$ Ibid. 
Fifth, he fond of having friendship or silaturabim. Kiai Sahal Mahfudh liked silaturahim, especially to most of ulama. Silaturabim is very important as a medium for purification of the heart and science development. Seeing a teacher can fill heart wit holy spirit and gain additional knowledge. Silaturabim to kiais is very important for good relationship and makes better attitude. Since becoming a student to become a great leader, Kiai Sahal Mahfudh was diligent to meet kiais, especially the elderly kiai. ${ }^{21}$ If there was something related to the family of the teacher, then Kiai Sahal Mahfudh would put forward a cultural approach with shillaturrahim. For example, when there was consensus in the region work Pondok Sarang held by NU Regional Board of Central Java, then Kiai Sahal Mahfudh went silaturabim to K.H. Maimun Zubair because in the evening he could not attend the event. It was a form of respect to the son of his teacher.

\section{Thought of K.H. M.A. Sahal Mahfudh}

Kiai Sahal Mahfudh is known as a teacher of figh and usul fiqh. His works in these two areas show the depth of understanding his wide perspective. His brilliant idea, which is still studied now is fiqh sosial. ${ }^{22}$ Fiqh Sosial is fiqh which responds actively and gives solution to social issues, such as poverty, education, health, and underdevelopment. Fiqh sosial was born of stagnation understanding of figh which is not able to understand the problems of real people in their contextual solutions. Fiqh sosial avoids black and white understanding, but develops it dynamically, creatively, and innovatively.

${ }^{21}$ Jamal Ma'mur Asmani, Fiqh Sosial Kiai Sabal Mabfudb: antara Konsep dan Implementasi, p. 24-25.

${ }^{22}$ Besides Kiai Sahal, another figure who develops figh sosial is K.H. Ali Yafie, read in K.H. Ali Yafie, Menggagas Fiqih Sosial (Bandung: Mizan, 1995). 
Fiqh understanding of Kiai Sahal Mahfudh is based on acute poverty that hit Kajen village and apathy of religionist in seeing this reality. According to Kiai Sahal Mahfudh, fiqh scientist should be able to provide a solution of the problem of poverty. If it can be, fiqh will lose relevance and the public will be further away from the guidance of fiqh. In order that figh is able to respond dynamically issue, then the understanding of fiqh can not be textual, eternal and absolute. Understanding of fiqh should always dynamically, in accordance with the demands of the times. Actualization and dynamicization of fiqh become the key to make fiqh as a tool of social engineering and social control. ${ }^{23}$

Fiqh sosial has five characteristics. First, contextualization of figh texts. This contextualization is needed to understand the historical context of the text, and then studies the main spirit of the text, and then contextualizes it according to contemporary life. Contextualization is particularly important because the understanding among schools and traditional Muslims are textual, that is, understanding the text lexically, not the whole, without learning the substance in the text and the historical background of this text. Contextualization encourages a person to understand the historical context of the text, take the main spirit, and do actualization according to the context.

Second, switching from mazhab qauTi to mazhab manhaji. This change as the development of the first step. If the existing text is not able to be a solution to the problem of the people, then uses manhaj (method) of ulama in producing the text. The development of mazhab qauti is done with contextualization of qawaid al-fiqh or contextualization of fiqh texts according to the dynamics of time. While mazhab

${ }^{23}$ Jamal Ma'mur Asmani, Mengembangkan Fikib Sosial K.H. M.A. Sahal Mabfudh (Jakarta: Quanta Gramedia, 2015), p. 140. 
manhaji is done by developing the theory of masalike al-illah integrated into the wisdom of the law, namely to bring benefit and prevent from damage. This is important to do so that religionist able to conduct breakthrough when stagnation of thought happens.

Third, verifying which the teaching of $u \bar{u} u$ (fixed) and which the teaching of furu' (not fixed) is. doctrine of $u s \bar{u} l$ is the doctrine in the category of qat'iyyat and mubleamat that is unchanged. The teachings in this category are few, because it does not become a field of ijtihad (majal al-ijtihäd), such as the obligatory of prayers, fasting, and pilgrimage. While the teachings of furu' $^{\prime}$ is the doctrine in the category of $z$ anniyyat and mutasyabibat that is used for ijtihad to generate comprehensive fiqh (sarwah fiqbiyyah). This doctrine of furu' can be developed dynamically and flexibly in order to adapt to the change of time, even it can inspire the change of the world.

Fourth, making fiqh as social ethics and not the positive law of the State. Formalization of Islamic law can potentially lead to the disintegration in the Republic of Indonesia (NKRI). Therefore, Formalization of religion should be avoided because Indonesia is not a religious state, but the state based on Pancasila and the Constitution of 1945. Kiai Sahal Mahfudh as well as the scholars of NU stipulated Pancasila as the nation's ideology embraced by the people of Indonesia and the Republic of Indonesia is the final form of the nation. Religion can be run independently by its adherents to be reserved. The substance of religion takes precedence and the formalities come second if it threatens NKRI and Pancasila. Unity and integrity are major capital of development, so all the things that disturb unity and must be prevented as early as possible. 
Fifth, the introduction of methods of philosophical thought, especially in the social and cultural issues. Philosophical thinking is thinking by looking at the structure of this premise to find the deepest essence. In the context of social, cultural, philosophical methods are needed to find the secret. Philosophical thought is very important to understand the cultural of the archipelago which full of intrinsic values. Walisongo inviting appreciative to the culture of the archipelago is an example of the application of philosophical thought so that the culture precisely used as instruments of effective propaganda in the propagation of Islam. ${ }^{24}$

In addition to fiqh sosial, Kiai Sahal Mahfudh has great attention to Islamic boarding school (pesantren) as an institution that is expected to create the ideal cadres of Islam. According to Kiai Sahal Mahfudh, Islmaic boarding school since its establishment the first time has become Aswaja (Ahlussunnah wal Jama'ah) as the basis of theology and belong to one of the four madzhab, Hanafi, Maliki, Shafi'i and Hanbali in the field of figh. ${ }^{25}$ Characteristic of pesantren as an educational institution is projecting the totality of the students personality. Educational philosophy of pesantren at first is the deepening of the religious sciences and sciences relating to religion. In the process, pesantren provides extensive knowledge to the students to become skilled workers who are able to play an active role in society. ${ }^{26}$ Nevertheless, the position of pesantren is a takhassus institution (specialization) in religion which is responsible to embed ethical values and nobility to the students. In addition, in order to create a cadre of qualified scholars, pesantren also equip the students with skills needed in the community.

${ }^{24}$ Ibid., p. 140.

${ }^{25}$ K.H. M.A. Sahal Mahfudh, Wajah Baru Fiqh Pesantren (Jakarta: Citra Pustaka and KMF Jakarta, 2004), p. 9.

${ }^{26}$ Ibid. 
Relevance of education in pesantren with the challenges of life becomes the homework of pesantren. Pesantren in this case should be able to produce a cadre of salih and akram. Salih was a man who has potential so that they can play an active role, useful, and skilled in public life. In this context, pesantren must equip the students with knowledge related to the needs of life. The akram is one's accomplishments related to the God to reach happiness hereafter. Therefore, pesantren emphasizes the deepening of religious knowledge (tafaqquh $\bar{f}$ ad-din) institutionally. However, pesantren is not only teaches religious knowledge, but also develops general sciences in an integrative manner. ${ }^{27}$

Kiai Sahal Mahfudh expected pesantren not only focused on the development of science, but also on the development of society. The leader of pesantren becomes referral sources of the community that has a religious thoughts in every activity, particularly in the development of society. If Pesantren has a role in the development of society, it must have skilled workers who are able to manage existing resources in boarding schools. If pesantren is able to develop the potential of education and society, it is expected to have ulama who has deep religious knowledge, extensive knowledge and insight into the horizon of thinking, but also to meet the demands of time in order to participate actively in solving the problems of society. ${ }^{28}$

In addition to figh sosial and pesantren, Kiai Sahal Mahfudh also examined the environment. According to Kiai Sahal Mahfudh, balance and preservation of the environment is the key welfare. Ironically, the current reality, life balance is already decreasing. This is due to the various outer

\footnotetext{
${ }^{27}$ Ibid.

${ }^{28}$ K.H. M.A. Sahal Mahfudh, Pesantren Mencari Makna (Jakarta: Pustaka Ciganjur and KMF Jakarta, 1999), p. 1-2.
} 
satisfaction without considering social discipline and does not anticipate the possibilities that make future generations difficult. $^{29}$ Welfare in this world and hereafter require building and preservation of the environment influenced by rational attitude who has extensive knowledge and attentive to others. ${ }^{30}$

Other thought of Kiai Sahal Mahfudh is khittah NU, 1926. As one of the important exponents in returning NU to khittah in the 27th congress in Situbondo 1984, Kiai Sahal Mahfudh socialized intensively to residents of NU at various forums. According to Kiai Sahal Mahfudh, khittah NU 1926 is the fundamental of thinking, behaving and acting of $\mathrm{NU}$ members which are reflected in the behavior of individuals, organizations, and in any decision-making. This conclusion was born of aspiration and inspiration of NU scholars who had common views and insights of religious and civic in 1918 by forming Syirkah 'Inan Murabathah Nahdlatut Tujjar. There are three of the fundamental motivation of $\mathrm{NU}$ scholars. First, the majority of NU members who behave resignation total (tajrid) without any attempt to improve the quality of life, so there was tama' attitude of the wealthy people. Second, many of the scholars and wealthy NU's do not care of the weak neighbors in religion, education and economy. Third, the majority of the students and kiai have enough with only tafaqquh $\overline{f i}$ ad-din within certain limits and do not care about the other sciences, and some even forbid it, so there is a gap between religious scholars and Muslim intellectuals Aswaja. ${ }^{31}$

Since NU was founded in 1926, NU khittah still lived by all board, both Syuriyah and Tanfidziyah. However, when the

\footnotetext{
${ }^{29}$ K.H. M.A. Sahal Mahfudh, Nuansa Fiqh Sosial, p. 376.

${ }^{30} \mathrm{Ibid}$.

${ }^{31}$ K.H. M.A. Sahal Mahfudh, Pesantren Mencari Makna, p. 199-200.
} 
founder had passed away or because of physical limitations, there was changes at NU, so that khittah 1926 became bleak and difficult to be internalized by NU members, even some leaders. By the time the $27^{\text {th }}$ Muktamar in Situbondo, NU lost its identity. Some of the indicators are a lack of sensitivity to social problems, acting reactively to respond any problems or issues without followed up by real action, and empowering creatively NU members did not get attention. those are the background behind the idea of returning to khittah 1926 starting $25^{\text {th }}$ congress in Surabaya in 1971. The history documents of founding NU studied intensively, especially in 1926 which clearly states that the scholars and followers of Aswaja always tried to manifest in a variety of programs, such as research and procurement of religious literature books, the development of dakwah, education and a touch of orphans and the poor, developing trade and commerce capabilities to improve the quality of life. ${ }^{32}$

The common thought of Kiai Sahal Mahfudh is to make religious texts, especially figh as an effective instrument in the transformation, especially in the economic. Justice and economic prosperity become a core value of Kiai Sahal Mahfudh thought that is manifested in the dedication and struggle for life. This is due to the condition of underdevelopment in Kajen and surroundings, so the paradigm of Muslims must be expanded so it is responsive to the change of the times and able to play competitively and productively in the international arena, not merely be an object that can be exploited.

\section{The Struggle of K.H. M.A. Sahal Mahfudh}

In building the transformative Islamic civilization, Kiai Sahal Mahfudh has some foundations of thoughts. First, Islam

\footnotetext{
${ }^{32}$ Ibid., p. 200-202.
} 
encourages Muslims become strong Muslim to be able to provide a great benefit to others extensively. Strong criterion is understood comprehensively, both in the field of aqidah, economic, political, scientific, cultural, and others. Muslims should not be a weak because the will be destroyed by nonMuslims and have no bargaining position in worldwide competition. Second, Islam encourages Muslims to fight, either with property or soul. Struggling with treasures requires them to have achievements in the economic field. Here is the urgency to generate entrepreneurship with a high work ethic. Poverty and backwardness must be overcome by a high work ethic with the undying spirit of entrepreneurship. ${ }^{33}$

Thirdly, Islam encourages Muslims to excel in the field of science by reading as a very representative activities in the context of learning knowledge. Muslims should not lose to non-Muslims, like Jews and Christians in developing sciences. Ironically, scientific achievement and the quality of educational institutions of Muslims is far below the Jews and Christians. It encourages all Muslims to devote all their capabilities to develop personal and institutional quality for the sake of izzu al-IsTam wa al-muslimin. Fourth, health becomes one of the basic needs of Muslims rarely noticed. While Islam always encourages Muslims to behave in a healthy life, such as healthy living, adequate rest, exercise, and avoiding things that are harmful to health, both mentally and physically. It is not realized by many Muslims, so that many of those who fell sick and powerless. Fifth, Islam encourages Muslims to care about others, either by charity, donation, and others. Islam's spirit of philanthropy should be raised to reduce social inequalities, especially in the economic field. The spirit of giving should be more emphasized than to receive. Management of zakat, donation, and alms should be

\footnotetext{
${ }^{33}$ K.H. M.A. Sahal Mahfudh, Nuansa Fiqh Sosial, p. 156-157.
} 
strengthened in order to be able to realize economic justice in Islam. Professional management with a strong team is the key to make Islamic philanthropy to be successful. ${ }^{34}$

From the foundation of thought above, Kiai Sahal Mahfudh build transformative Islamic civilization. There are several aspects that are prioritized by Kiai Sahal Mahfudh in building a civilization. First, making pesantren as an institution that has two functions, namely science and society. The function of science is manifested by optimizing tafaqquh $\overline{f i}$ ad-din (deepening the religious knowledge). The students should be able to explore the whole of the yellow book, both in terms of esoteric and its esoseris. While social function is realized in the form of economic empowerment. Kiai Sahal Mahfudh makes Maslakul Huda pesantren as a vehicle for regeneration with profound science. Fiqh and usul figh become a focus of study at Maslakul Huda Islamic boarding school. Kiai Sahal Mahfudh read the book of usul

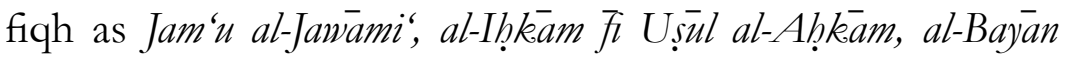
al-Mulamma' 'an Alfaza al-Luma', Mawähib as-Sanniyyah, and others. In addition, Kiai Sahal Mahfudh also formed BPPM (Pesantren and Community Development Bureau) engaged in economic empowerment in Kajen and surroundings. BPPM acts as a catalyst, facilitator, motivator and inspiration behind the economic revival of the people. BPPM conducts program of training, mentoring, counseling, provision of capital, and periodic evaluation to monitor the economic activities of the people.

Second, education becomes the key to the triumph of the people and nation. Education in charge of improving the quality of young generation that will be the doer of development in the future. If education fails in bringing qualified generations, then the future of this nation is

\footnotetext{
${ }^{34}$ Ibid., p. 145-146.
} 
threatened. Education in charge of internalizing positive character traits, such as honesty, discipline, optimism, never give up, creative, innovative, and nationalists. Education is also in charge of equipping the intellectual as professional competence in going global competition. Kiai Sahal Mahfudh raised the quality of education, both at the Islamic Institution of Mathali'ul Falah (PIM) Kajen Margoyoso Pati and at the Islamic Institute of Nahdlatul Ulama (INISNU). Kiai Sahal Mahfudh encourages teachers and students to improve reading as a source of knowledge and information that is very useful in improving the intellect and intelligence. Kiai Sahal Mahfudh also encourages human beings to develop education for writing scientific and record it. Kiai Sahal Mahfudh provides exemplary by writing Arabic language books and papers presented at various scientific forums. In the end, Kiai Sahal Mahfudh initiated the establishment of the Islamic High School of Mathali'ul Falah (STAIMAFA) that is now changed into the Institute of Mathali'ul Falah Islamic School (IPMAFA) with a vision "To Be Research High School Based Pesantren Values".

Third, health became the great concern of Kiai Sahal Mahfudh. Therefore, Kiai Sahal Mahfudh pioneered the establishment of the hospital with K.H. Abdullah Salam, his uncle. At first, Kiai Sahal Mahfudh established a health clinic, then after developing Islamic Hospital (RSI) Pati was established under the auspices of the Foundation NU's Pati. Kiai Sahal Mahfudh wanted Muslims in a healthy condition so that they can work, learning knowledge, and work to accelerate development in all aspects of life. Fourth, Kiai Sahal Mahfudh makes the social dimension of religious doctrine, not dogmatic without a touch of social. From here, Kiai Sahal Mahfudh moved spirit of Islamic philanthropy for upholding the community economic justice. Zakat 
is interpreted contextually and transformatively. Zakat is not only given to mustahiq, but should be managed professionally with a solid team that is able to pull out the people of poverty to prosperity. ${ }^{35}$

Fifth, Kiai Sahal Mahfudh supports democracy and rejects authoritarianism and tyranny of the majority. Democracy provides space for all elements of society to express their aspirations and transformative ideas. In a democracy, decisions made are the majority opinion that reflects the interests of the majority. In a democracy, Muslims must demonstrate competence so able to color it with transformative thinking and action to achieve the glory of the nation in the future. Islam should not be opposed to democracy, because it should be an inspiration of democration. In Indonesia, nationalism is proved by Kiai Sahal Mahfudh in his social works. His deep love for this nation is indicated by a lifelong struggle to eradicate poverty and backwardness of the people. As the highest leader in NU and MUI, Kiai Sahal Mahfudh fight tenaciously upholding of democracy, justice, and social welfare.

\section{Movement of Kiai Sahal Mahfudh Based on Maqāṣid asy-Syari'‘ah}

Transformative changes in the concept and championed Kiai Sahal Mahfudh refers to the establishment of maqasid asy-syari'ah, objectives of Islamic law, which is keeping the religion, life, property, intellect, and offspring. Keep the five basic rights is the essence of religion in the realization of the benefit. According to Imam al-Ghazali, the benefit is to bring expediency or deny the danger. Bring benefit and deny the danger is to achieve the goal of religion, and not a human purpose and human goodness. The purpose according to

${ }^{35}$ Jamal Ma'mur Asmani, Zakat Solusi Mengatasi Kemiskinan Umat (Yogyakarta: Aswaja Pressindo, 2016), p. 17-21. 
Islamic law of humans there are five, namely to maintain their religion, their souls, their minds, their descendants, and their property. Every lesson that contains to keep the five main based is the benefit and any lessons that negates five are the main base of damage and reject it is welfare. ${ }^{36}$ Maintains that five basic rights are necessary (daruriyyat) for the benefit of the most powerful level. For example, the punishment for those who make the bid'ah that encourages others to follow his bid'ah, qișas punishment (equal punishment to the crime someone) to maintain religion, punishment for people drinking wine, the punishment of people who commit adultery, and punishment for looters and thieves. ${ }^{37}$

Another example is in order to keep religion do with doing things that strengthen faith, such as planting creed and prevent any damaging things, like kufr and shirk. Keeping the soul by improving the safety, comfort, and safety of all disturbances. Answering the treasure be done by increasing revenue and reducing poverty and economic underdevelopment that could destroy religion. Keeping sense is done by improving the quality of intensive education for cadres Islam that capable and professional. Keeping descent is done by strengthening the moral and mental and prevents anything that may lead to free sex, and others.

Right now in the context of modern world, the theory of maqașid asy-syari'ah be developed progressively. One was conducted by Jasser Auda. Development of sense not only prohibits liquor, but also develops scientific thinking, trips studying, preventing the flow of overseas experts, and against the mentality of imitation. Maintain the honor

\footnotetext{
${ }^{36}$ Imam al-Ghazali, al-Mustasfă min Tlm al-Ușül (Kairo: Maktabah Wahbah, 1992), juz 2, p. 481-482. See also K.H. Ahmad Munif Suratmaputra, Filsafat Hukum Islam alGhazali (Jakarta: Pustaka Firdaus, 2002), p. 125.

${ }^{37}$ K.H. Ahmad Munif Suratmaputra, Filsafat Hukum Islam al-Ghazali, p. 126127.
} 
and the soul are developed with the protection of human dignity even to the protection of human rights. Maintain the property developed into economic development, public welfare, reduction of between socio-economic classes, social assistance, and others. Keeping religion developed into freedom of belief or freedom of believed. ${ }^{38}$ Thought maqasid asy-syari'ah will continue to evolve according to social dynamics.

\section{Kiai Sahal Mahfudh Strategy in Developing Transformative Islamic Civilization}

Kiai Sahal Mahfudh successfully build transformative Islamic civilization, resulting in a significant improvement in the economic, educational, and political people. Kiai Sahal Mahfudh success cannot be separated from Kiai Sahal Mahfudh in managing strategy. Kiai Sahal Mahfudh strategies in building the Islamic civilization transformative are:

First, perform regeneration. One of the secrets Kiai Sahal Mahfudh make a breakthrough in various fields is his intelligence in the cadre of people according to their talents and expertise. In a pioneering program in community economic empowerment BPPM, Kiai Sahal Mahfudh choose Mr. Masyhud Musyaffa' and Masykur Maskub in a program organized by LP3ES (Institute for Educational Research and Development of Economic and Social Affairs) Jakarta. ${ }^{39}$ In the banking management, Kiai Sahal Mahfudh choose Mr. Zabidi Ahmad Najib who have a very strong culture of boarding schools as the son of a kiai, namely Kiai Zabidi. Under the touch of Mr. Ahmad Najib, Artha Huda Abadi growing massively, so as to set up branches in various regions, either in or outside Pati Pati. In the field of education,

\footnotetext{
${ }^{38}$ Jasser Auda, Membumikan Hukum Islam Melalui Maqasid Syariah, trans. Rosidin and Ali Abd el-Mun'im (Bandung: Mizan, 2015), p. 57-59.

${ }^{39}$ Ibid.
} 
Kiai Sahal Mahfudh put reliable cadres in the ranks of his subordinates to manage educational institutions in a dynamic and productive, both in Mathali'ul Falah Islamic University and the Islamic Institute Pati Nahdlatul Ulama (INISNU) Jepara. In the organization, such as NU and MUI, Kiai Sahal Mahfudh put people to take care of it professionally.

Second, Kiai Sahal Mahfudh took a risk when started a change. When Maslakul Huda is promoting economic empowerment of the people, a lot of accusations and criticisms of the kiai in Kajen. Kiai Sahal Mahfudh be accused Zionist agent because it cooperated with the founding of foreign non-Muslim. Kiai Sahal Mahfudh facing all the criticism and insults with patience, tough, and resilient. He remained consistent movement changes. When Kiai Sahal Mahfudh change movement, especially in the economic field began to take shape, slowly but surely, people appreciate Kiai Sahal Mahfudh. For a long time, the other Kiai realize the noble objectives Kiai Sahal Mahfudh to improve the welfare of the people as a condition for achieving progress in all fields.

Third, intellectual and social capital are very strong. Kiai Sahal Mahfudh is a warrior science of fiqh and usul fiqh which are the base of scientific schools. Kiai Sahal Mahfudh expertise in the field of figh and usul fiqh recognized almost Kiai in Kajen and surrounding areas. In addition, social capital Kiai Sahal Mahfudh is strong. He was the son of a prominent scientist and a drive for independence, namely K.H. Mahfudh Salam and grandchildren a great scholar whose charismatic Kajen, namely K.H. Abdussalam. Paths father and his extended family Kiai Sahal Mahfudh put in a very high social position in Kajen and surrounding areas.

Fourth, Kiai Sahal Mahfudh developed a wide network, so that it can be used to drive change in a positive and 
constructive in Kajen. Cross-sectoral association Kiai Sahal Mahfudh with bureaucrats, academics, non-governmental organizations (LSM), media, and others strongly support breakthroughs Kiai Sahal Mahfudh in economics, health, and education.

Fifth, personally, Kiai Sahal Mahfudh is a humble figure, even tend hum $\bar{u} l$, which hides excellence and greatness. When the early days came from the nest, Kiai Sahal Mahfudh couldn't want to read the book openly because there are many seniors kiai living. Keeping feelings and his position as junior student is very important for psychology in boarding schools to maintain the solidarity and cohesiveness Kiai. Kiai Sahal Mahfudh realize that understanding the context is very important that what is said and done is not counterproductive but always brings refreshment and good change gradually.

\section{Developing Transformative Civilizations by Kiai Sahal Mahfudh}

\section{a. To develop transformative civilization pioneered and driven Kiai Sahal Mahfudh Mahfudh takes a few steps.}

First, the dynamics of thinking by developing a study according to scientific specifications, such as the al-Qur'an, hadis, figh, ushul figh, tauhid, and others. The study center is very important for the study focuses on the fields of science so that the birth of great works, not split into many fields as a result less than the maximum. Study of the al-Qur'an center which was pioneered and nurtured Prof. Dr. M. Quraish Shihab is one example of a good study centers for areas of study focus, so as to produce many works of high quality. At the Institute of Mathali'ul Falah Pesantren (IPMAFA) has been established Center for the Study of Social Pesantren and Fiqh (PUSAT FISI) is focused on the study of figh 
schools and social. PUSAT FISI is already produced many weighty works in the field of social fiqh, especially those initiated by Kiai Sahal Mahfudh Mahfudh. In the future need to be initiated Study Center for Economic Empowerment Ummah to examine in depth models of effective economic empowerment of the people that were create the highquality works as a guide for practitioners in empowering the community economic potential.

Second, develop the spirit of entrepreneurship so that people going economic revival. Kiai Sahal Mahfudh has pioneered bank as providers of capital and moving BPPM economic empowerment of the people. Kiai Sahal Mahfudh movement must be continued and developed by developing Entrepreneurship Training Center in cooperation with banks to make young creative entrepreneur, productive, and competitive. This training center should be completed by scientists in the fields of economics and good quality practitioners already able in the business world, so as to have a strong charisma to train and mobilize the entrepreneurial world.

Third, develop an international standard hospital. This time Islamic hospitals less than Christian hospital, both in terms of quality of medical personnel, management, infrastructure, facilities, and networks to the outside. Islamic hospital must develop them accelerated and escalated to be able to keep pace and achieve great accomplishments so as to become the main reference of Muslims and the nation as a whole.

Fourth, encourage the creation of a harmonious civil society building and transformative as evidence of the strength of nationalism and patriotism. Unity is the foundation of the nation that must be maintained collectively. Each disintegration potential of the nation must be prevented 
as early as possible. Islam should be the religion to unite the nation, not vice versa, as the religion of a nation breaker. The toil of the founding fathers who seize freedom with a capital of unity and must be treated to reach the glory of the nation in all aspects of life.

Fifth, build human civilization is promoting the values of divinity, humanity, justice, prosperity, equality, and peace. The world should be decorated with positive values capable of illuminating the Muslims with goodness and truth and avoid injustice, misery and barbarity against the noble teachings of religion and human rights.

This five above requires collaboration between all elements, both from the scientific community, the bureaucracy, NGOs, the media, religious leaders (ulama), community leaders, and all elements of the nation. In the context, it is urgent to call young cadres reliable to be involved in this major project in order to accelerate the triumph of the people and nation in the future. It is unfortunate if the young cadres of reliable, both graduates of the schools, universities and abroad, forgotten, then they choose to serve in other institutions. The speed required to capture this opportunity needed. Do not let young workers taken by others. Foresight to read the potential of young people be the key to drive change constructively towards a bright future.

\section{Conclusion}

K.H. M.A. Sahal Mahfudh is the figure of thinkers, leaders and agents of change in society with many kinds of achievements. Legacy monumental abandoned K.H. M.A. Sahal Mahfudh is intellectual and social work as well. K.H. M.A. Sahal Mahfudh successful in establishing Islamic civilization capable implies transformative values of progress 
of the people, especially in the fields of education, economy, health, and universal culture.

Fiqh sosial as Kiai Sahal Mahfudh legacy in the realm of thought until now still continue to be studied because they are relevant to the challenges of the times. The phenomenon of radicalism and religious fundamentalism is one of the challenges that can respond to the social figh perspective. Maslakul Huda Islamic School, Mathali'ul Falah Islamic University, Institute Mathali'ul Falah Islamic School, Islamic Hospital, and BPR Arta Huda are Kiai Sahal Mahfudh legacy in the field of social practical until now continues to spread the spirit of knowledge, empowerment and entrepreneurship.

It's challenging for Muslims, especially young cadres to carry forward and develop the legacy K.H. M.A. Sahal Mahfudh. Young cadres should not feel quite the accomplishment carved Kiai Sahal Mahfudh. With the spirit of transformation Kiai Sahal Mahfudh, young cadres must instead be motivated more to pioneer new things that benefit the wider community, both in the areas of education, economy, health, and human culture. 


\section{REFERENCES}

Auda, Jasser. Membumikan Hukum Islam Melalui Maqasid Syariah, trans. Rosidin dan Ali Abd el-Mun'im. Bandung: Mizan, 2015.

Asmani, Jamal Ma'mur, Figh Sosial Kiai Sabal Mabfudh Mahfudh: antara Konsep dan Implementasi. Surabaya: Khalista, 2007.

- Mengembangkan Fikib Sosial K.H. M.A. Sahal Mabfudh: Elaborasi Lima Ciri Utama. Jakarta: Quanta Gramedia, 2015.

dkk. Mempersiapkan Insan Sholih-Akrom: Potret Sejarah dan Biografi Pendiri-Penerus Perguruan Islam Mathali'ul Falah Kajen Margoyoso Pati 1912-2012 (1 Abad). Pati: PIM, 2012.

. Zakat Solusi Mengatasi Kemiskinan Umat. Yogyakarta: Aswaja Pressindo, 2016.

al-Ghazali, Imam. al-Mustaşfa min Tlm al-Ușul. Kairo: Maktabah Wahbah, 1992.

Karim, M. Abdul. Sejarah Pemikiran dan Peradaban Islam. Yogyakarta: Bagaskara, 2012.

Mahfudh, K.H. M.A. Sahal. Nuansa Figh Sosial. Yogyakarta: LKiS, 1994.

. Pesantren Mencari Makna. Jakarta: Pustaka Ciganjur and KMF Jakarta, 1999.

- Fiqh Sosial: Upaya Pengembangan Mazhab Qauli dan

Manhaji. Jakarta: UIN Syarif Hidayatullah, 2003. . Wajah Baru Figh Pesantren, ed. Aziz Hakim Saerozy. Jakarta: Citra Pustaka and KMF Jakarta, 2004. 
Mas'ud, Abdurrahman. Reproduksi Ulama di Era Globalisasi. Yogyakarta: Pustaka Pelajar, 2005.

Nasution, Harun. Pembaharuan dalam Islam: Sejarah Pemikiran dan Gerakan. Jakarta: Bulan Bintang, 2003.

- Islam Ditinjau dari Berbagai Aspeknya, Jilid 1. Jakarta: UI Press, 2008.

Rahman, Fazlur. Islam. US: University of Chicago, 1979.

Rahman, Mujib, dkk. Kiai Sahal Mahfudh: Sebuah Biografi. Jakarta: KMF Jakarta, 2012.

Suratmaputra, K.H. Ahmad Munif. Filsafat Hukum Islam al-Ghazali: Maslahah Mursalah dan Relevansinya dengan Pembaharuan Hukum Islam. Jakarta: Pustaka Firdaus, 2002.

Wijdan S.Z., Aden, dkk. Pemikiran dan Peradaban Islam. Yogayakarta: PSI UII and Safiria Insania Press, 2007.

Yafie, K.H. Ali. Menggagas Fiqih Sosial. Bandung: Mizan, 1995.

Yatim, Badri. Sejarah Peradaban Islam. Jakarta: RajaGrafindo Persada, 2011. 